\title{
MANAJEMEN DAN KEPEMIMPINAN PENDIDIKAN ISLAM: MENCARI FORMAT BARU MANAJEMEN YANG EFEKTIF DI ERA GLOBALISASI
}

\author{
Oleh: Tobroni \\ Universitas Muhammadiyah Malang
}

\begin{abstract}
Abstrak
Berbagai penelitian menunjukkan bahwa untuk merubah dari siklus negatif menjadi siklus positif atau untuk merubah dari sekolah yang tidak berkualitas (bad school) menjadi sekolah berkualitas (good school), faktor kepemimpinan memegang peran yang sangat menentukan. Lembaga pendidikan yang baik dipimpin oleh pemimpin yang baik, walaupun tidak semua pemimpin yang baik mampu menjadikan lembaga pendidikan menjadi baik. Bagi lembaga pendidikan Islam yang menghadapi persoalan berat dan misi yang sangat mulia (pendidikan dan dakwah), perlu dipimpin oleh pemimpin yang memiliki kekuatan luar biasa. Model kepemimpinan konvensional seperti kepemimpinan situasional, transaksional dan transformasional perlu disempurnakan dengan model kepemimpinan spiritual. Kepemimpinan spiritual adalah kepemimpinan yang mendasarkan visi, misi dan perilaku kepemimpinannya pada nilai-nilai ketuhanan.
\end{abstract}

Kata Kunci: manajemen, kepemimpinan, pendidikan Islam 


\section{A. Tantangan Internasionalisasi dan Globalisasi}

Dalam perbincangan sehari-hari, istilah internasionalisasi kurang populer dibandingkan dengan istilah globalisasi. Internasionalisasi dan globalisasi Menurut Sofyan Effendi ${ }^{1}$ ibarat kembar siam yang hampir sama bentuk fisiknya tetapi berbeda sifat dan wataknya. Penulis mengibaratkan sebagai dua bentuk kolesterol dalam tubuh manusia. Yang pertama (internasionalisasi) diidentikkan dengan kolesterol baik (HDL) yang sangat dibutuhkan oleh manusia, sedang yang kedua (globalisasi) diidentikkan dengan kolesterol jahat (LDL) yang memang jahat, brutal, dan rakus lagi tamak.

Dunia pendidikan sudah seharusnya diselenggarakan dengan semangat dan orientasi internasional. Hadis Rasulullah yang sangat terkenal memerintahkan umatnya untuk menuntut ilmu sampai ke negeri Cina (negeri yang jauh). al-Qur'an Surat at-Taubah ayat 122 secara tersirat memerintahkan umatnya untuk menuntut ilmu di tempat yang jauh sehingga kalau nantinya kembali dapat memberikan peringatan, pencerahan dan pemberdayaan bagi kaumnya. ${ }^{2}$ Internasionalisasi pendidikan merupakan keniscayaan apabila sebuah bangsa ingin memiliki peradaban yang unggul. Pendidikan Islam pada masa Rasulullah sampai abad ke-13 memiliki semangat, orientasi internasional yang kuat. Salah satu contohnya adalah getolnya ilmuwan Muslim untuk mempelajari filsafat dan ilmu pengetahuan Yunani dan Romawi untuk diterjemahkan, dikritisi dan dikembangkan sehingga melahirkan pemikiran, ilmu dan teknologi baru. Sesungguhnya ilmu pengetahuan, seni dan peradaban itu sabda Rasululah merupakan "hikmah yang hilang, dimanapun dan kepada siapapun, ambillah".

Baru-baru ini, semangat internasionalisasi pendidikan mulai berkembang di Indonesia, misalnya dengan dibukanya Sekolah Nasional Bertaraf Internasional (SNBI). Juga semakin banyaknya google.com

${ }^{1}$ Sofian Effendi. 2007. Menghadapi Liberalisasi Pendidikan Tinggi. http//www.

2 "Tidak sepatutnya bagi orang-orang yang beriman itu pergi semuanya (ke medan perang). Mengapa tidak pergi dari tiap-tiap golongan di antara mereka beberapa sejumlah orang untuk memperdalam pengetahuan tentang agama (ilmu pengetahuan) dan untuk membei peringatan kepada kaumnya apabila mereka telah kembali kepadanya, supaya mereka itu dapat menjaga dirinya". 
lembaga pendidikan yang melakukan akreditasi dan standarisasi tidak hanya oleh Badan Akreditasi Nasional (BAN), tetapi juga oleh badan regional dan internasional semacam Asean Univercity Network (AUN), Association of Southeast Asia Institute of Higher Learning (ASAI-HL), ataupun International standard Organization (ISO). Semakin berkembang sekolah atau perguruan tinggi yang menjalin kerjasama dalam berbagai bentuk seperti pertukaran guru dan pelajar, pengadaan pilot project bersama, twining programs, sisters schools, dan lain sebagainya.

Sedangkan globalisasi lebih bersifat pemaksaan kehendak, aspirasi dan kepentingan negara maju terhadap negara sedang berkembang untuk melakukan integrasi dalam pasar bebas bersama. Melalui Multi National Corporation (MNC) dan Trans National Corporation (TNC) yaitu Bank Dunia (World Bank), International Monetary Foundation (IMF) dan Organisasi Perdagangan Dunia (world Trade Organization/WTO) globalisasi membonceng neo capitalism, neo liberalism dan neo colonialism. Menurut Stiglitz ${ }^{3}$, globaliasi merupakan interdependensi yang asimetris (tidak sejajar) antar-negara, lembaga, dan aktornya. Negara berkembang yang serba terbatas kemampuan dan ketercukupannya di bidang sumber daya manusia, ilmu pengetahuan dan teknologi, ekonomi, sistem organisasi, sistem politik, sistem informasi dan komunikasi dan lain sebagainya harus bersaing dengan bebas (tanpa proteksi) dengan kekuatan negara maju yang dimotori oleh Amerika Serikat, Inggris dan Australia. Persaingan dan pertandingan ini dapat diibaratkan petinju kelas terbang mini yang harus bertanding dengan petinju kelas berat. Karena itu, interdependennsi yang seperti itu jelas lebih menguntungkan negara-negara maju. Padahal, globalisasi awalnya dikampanyekan untuk membuka peluang bagi negara-negara berkembang guna meningkatkan kesejahteraannya melalui perdagangan global itu tidak terbukti sama sekali, karena yang terjadi justru sebaliknya yaitu tatanan dunia yang penuh dengan ketidakadilan, dan bahkan penindasan dan penjajahan baru (neo colonialism).

Menurut Effendi 4 , logika yang mendasari ekspansi globalisasi gelombang ketiga diturunkan dari ideologi neoliberalisme, yang di dalam filsafat politik kontemporer memiliki afinitas dengan ideologi

\footnotetext{
${ }^{3}$ Dalam, Sofian Effendi, ibid. hlm. 4

${ }^{4}$ Sofian Effendi, ibid.
} 
libertarianisme yang direntang melampaui batasnya yang ekstrem. Seperti halnya dengan libertarianisme yang membela kebebasan pasar dan menuntut peran negara yang terbatas, neoliberalisme percaya pada pentingnya institusi kepemilikan privat dan efek distributif dari ekspropriasi (pengambil-alihan) kemakmuran yang tidak terbatas oleh korporasi-korporasi transnasional.

Apa akibatnya kalau pendidikan termasuk bagian dari komoditi dan komersialisasi sistem ekonomi global? Bagaimana strategi pendidikan Islam menghadapi hal itu? Benarkah globalisasi justru menawarkan peluang yang lebih menjanjikan bagi pendidikan untuk mewujudkan pendidikan bermutu internasional sebagaimana yang mungkin diyakini banyak ahli ekonomi?

\section{B. Dampak Globalisasi bagi Pendidikan Islam}

Globalisasi yang berkembang sekarang ini berwajah fundamentalisme pasar bebas dengan berbagai instrumen pendukungnya jelas tidak menguntungkan negara berkembang, namun globalisasi seperti itulah yang justru "dipaksakan" kepada negara-negara berkembang oleh negara maju melalui "gurita" pasar bebas yaitu IMF, Bank Dunia dan WTO. Dampak globalisasi di bidang pendidikan jelas menguntungkan negara-negara maju. Masih menurut Sofyan Ef-fendi (2007), tiga negara yang paling mendapatkan keuntungan besar dari liberalisasi jasa pendidikan adalah Amerika Serikat, Inggris, dan Australia. Pada 2000 ekspor jasa pendidikan Amerika mencapai USD 14 miliar atau 126 triliun rupiah. Di Inggris, sumbangan pendapatan dari ekspor jasa pendidikan mencapai $4 \%$ dari penerimaan sektor jasa negara tersebut. Sebuah publikasi rahasia berjudul Intelligent Eksport mengungkapkan bahwa pada 1993 sektor jasa telah menyumbangkan $20 \%$ pada PDB Australia, menyerap $80 \%$ tenaga kerja dan merupakan $20 \%$ dari ekspor total negeri kanguru tersebut.

Negeri-negeri Muslim di seluruh dunia yang berpenduduk \pm 1,3 milyard jiwa, merupakan salah satu negara-negara tujuan eksportir jasa pendidikan dan pelatihan dari negara-negara maju. Hal ini disebabkan karena, pertama, perhatian umat Islam dan pemerintah negera-negara di dunia muslim terhadap bidang pendidikan masih rendah. 
Kedua, secara umum mutu pendidikan negeri-negeri Muslim dari sekolah dasar sampai peguruan tinggi, jauh tertinggal dari standar mutu internasional. Kedua alasan tersebut sering menjadi alasan untuk "mengundang" masuknya penyedia jasa pendidikan dan pelatihan luar negeri ke negeri-negeri Muslim. Untuk lebih meningkatkan ekspor jasa pendidikan ke negara-negara berkembang, intervensi pemerintah dalam sektor jasa tersebut harus dihilangkan. Liberalisasi semacam itulah yang hendak dicapai melalui General Agreement on Trade in Services (GATS).

Khusus di Indonesia, hingga saat ini enam negara telah meminta Indonesia untuk membuka sektor jasa pendidikan yakni Aus-tralia, Amerika Serikat, Jepang, China, Korea, dan Selandia Baru. Sub sektor jasa yang ingin dimasuki adalah pendidikan tinggi, pen-didikan seumur hayat, dan pendidikan vokasi dan profesi. Pendidikan dari perspektif industri tersier memiliki makna ganda: ekonomi, politik, budaya dan bahkan ideologis. Yang melatarbelakangi para provider pendidikan (negara-negara maju) untuk membangun pendidikan di Indonesia tidak bisa dilepaskan dari motif-motif tersebut. Dampak negatif dari hal ini adalah banyaknya pendidikan dalam negeri terutama swasta Islam yang kalah bersaing dan kemungkinan mengakibatkan gulung tikar. Secara politik, ekonomi, budaya, nasionalisme dan islamisme anakanak Indonesia bisa saja akan mengalami persoalan.

Sebagaimana kita ketahui bahwa pendidikan mempunyai tiga tugas pokok, yakni: pertama, nation and character building atau civic mission. Pendidikan sangat vital peranannya dalam mentransfer nilai-nilai dan jati diri bangsa; kedua, empowering of human resource melalui upaya mentransfer dan mengembangkan ilmu pengetahuan, teknologi, seni dan budaya; dan ketiga, dalam konteks Islam, pendidikan merupakan salah satu media dakwah yang paling efektif. Karena itu, setiap upaya untuk menjadikan pendidikan dan pelatihan sebagai komoditas yang tata perdagangannya diatur oleh lembaga internasional, bukan oleh otoritas suatu negara, perlu disikapi dengan semangat nasionalisme dan Islamisme yang tinggi serta dengan kritis oleh masyarakat negara berkembang. 


\section{Strategi Pendidikan Islam Menghadapi Globalisasi}

1. Perspektif Mikro Kelembagaan

Sebagaimana dikemukakan di muka, globalisasi dan internasionalisasi disamping mempunyai perbedaan juga ada persamaannya. Persamaannya adalah adanya interkoneksitas antar bangsa-bangsa di dunia. Sedang pebedaannya, kalau internasionalisasi berarti go internasional yang artinya kita aktif dan terdapat hubungan yang simetris. Sedangkan globalisasi berarti sebaliknya yaitu terpengaruhi, termasuki dan bahkan terkooptasi oleh keadaan global yang dimotori oleh "gurita"nya yaitu IMF, Bank Dunia dan W'TO. Dalam globalisasi, pendidikan Islam berada di pihak yang pasif sebagai akibat dari hubungan yang asimetris atau persaingan yang tidak seimbang.

Karena globalisasi pendidikan sudah terjadi di dalam berbagai negara sehingga negara-negara muslim yang merupakan negara sedang berkembang juga tidak dapat menolak globalisasi pendidikan tersebut, maka dalam perspektif mikro kelembagaan pendidikan yang harus dilakukan oleh penyelenggara pendidikan Islam negara-negara Muslim salah satunya adalah dengan melakukan analisis SWOT (strength, weakness, opportunity dan threat):

Langkah pertama, identifikasi kelemahan (internal, pendidikan Islam) dan ancaman (eksternal, globalisasi) yang paling urgen untuk diatasi secara umum pada semua komponen pendidikan.

Langkah kedua, identifikasi kekuatan (internal) dan peluang (eksternal) yang diperkirakan cocok untuk mengatasi kelemahan dan ancaman yang telah diidentifi kasi pada langkah pertama.

Langkah ketiga, melakukan analisis SWOT lanjutan setelah diketahui kekuatan, kelemahan, peluang dan ancaman dalam konteks sistem manajemen pendidikan.

Langkah keempat, rumuskan strategi-strategi yang direkomendasikan untuk menangani kelemahan dan ancaman, termasuk pemecahan masalah, perbaikan dan pengembangan lebih lanjut.

Langkah kelima, tentukan prioritas penanganan kelemahan dan ancaman itu dan disusun suatu rencana tindakan untuk melaksanakan program penanganan.

Setelah melakukan analisis SWOT, berikutnya adalah melakukan langkah-langkah strategis sebagaimana dapat dibagankan seb- 
agai berikut ${ }^{5}$ :

ANALISIS KKPA [SWOT]

\begin{tabular}{|c|c|c|}
\hline $\begin{array}{l}\text { Faktor } \\
\text { Interna } \\
\text { Faktor } \\
\text { Eksternal }\end{array}$ & $\begin{array}{l}\text { Kekuatan } \\
\text { [S] }\end{array}$ & $\begin{array}{l}\text { Kelemahan } \\
{[W]}\end{array}$ \\
\hline \multirow[b]{2}{*}{$\begin{array}{c}\text { Peluang } \\
\text { [O] }\end{array}$} & Strategi SO & Strategi WO \\
\hline & $\begin{array}{c}\text { Gunakansintuk } \\
\text { memanfaatkan "o" } \\
\text { Ekspansi }\end{array}$ & $\begin{array}{l}\text { Menghilangkan "W" } \\
\text { dan memanfaatkan " } \mathrm{O} \text { " }\end{array}$ \\
\hline \multirow{2}{*}{${ }_{[T]}^{\text {Ancaman }}$} & \multicolumn{2}{|c|}{$\underset{\text { Strategi ST }}{\text { Konsolidasi }}$} \\
\hline & $\begin{array}{l}\text { Gunakan "S" untu } \\
\text { Menghindarkan "T }\end{array}$ & $\begin{array}{l}\text { nalkan "W" untuk } \\
\text { hindarkan "T", }\end{array}$ \\
\hline
\end{tabular}

Dengan analisis SWOT tersebut diharapkan pendidikan Islam dapat melakukan langkah-langkah strategis.

Strategi SO. Inilah yang paling diharapkan, dimana pendidikan Islam dapat mengkonsolidasikan dan memobilisasi kekuatan (sumberdaya: integritas, manusia, governance, organisasi, informasi, fi nansial, fi sik dan fasilitas) untuk memanfaatkan peluang yang ada guna melakukan ekspansi. Inilah yang disebut keberuntungan, yaitu bertemunya kekuatan (kesiapan) dengan peluang.

Strategi WO. Yaitu dengan cara mengeliminir kelemahan untuk selanjutnya mendayagunakan peluang. Kalau diibaratkan seorang pedagang yang tidak punya modal tetapi ada kesempatan untuk meraup keuntungan, maka yang dilakukan adalah memfokuskan pada upaya mendapatkan keuntungan sambil berusaha mendapatkan modal. Bukan meratapi kelemahannya sehingga peluang hilang.

Strategi ST. Yaitu dengan cara melakukan konsolidasi untuk meningkatkan dan mendayagunakan kekuatan guna menetralisir, menghindari ancaman atau merubah ancaman menjadi peluang. Realitanya, apa yang didefi nisikan sebagai ancaman pada dasarnya belum tentu ancaman yang sesungguhnya. Misalnya, pada pertengahan tahun 1970-an ketika diterbitkan SKB Tiga Menteri tentang kesetaraan madrasah dengan sekolah umum, banyak kalangan menilai se-

\footnotetext{
${ }^{5}$ Badan Akreditasi Nasional Perguruan Tinggi, (Depdiknas, tahun 2005), hlm. 28.
} 
bagai ancaman terhadap eksistensi madrasah dan dakwah islamiyah. Fakta membuktikan SKB itu justru memberikan peluang bagi ma-drasah untuk lebih berkembang di masa-masa berikutnya. Contoh lain misalnya tentang pesantren masuk GBHN. Banyak yang menilai akan merusak jati diri dan kemandirian pesantren. Padahal bisa jadi dengan pesantren masuk GBHN akan merupakan amunisi baru untuk kemajuan pesantren.

Stategi WT. Yaitu meminimalkan kelemahan untuk menghindari ancaman. Ini merupakan keadaan yang paling tidak diharapkan. Pesantren dan madrasah swasta banyak yang menghadapi masalah ini, dimana secara internal memiliki kelemahan di hampir semua komponen, sedang secara eksternal menghadapi ancaman, seperti persaingan yang ketat atau krisis kepercayaan masyarakat.

\section{Analisis KKPA}

\begin{tabular}{|c|c|}
\hline $\begin{array}{l}S>W \\
O>T\end{array}$ & ekspansi keluar \\
\hline $\begin{array}{l}\mathbf{S}<\mathrm{W} \\
\mathbf{O}<\mathrm{T}\end{array}$ & konsolidasi ke dalam \\
\hline
\end{tabular}

Dwatma dji

\section{Perspektif Makro}

Sedangkan dari perspektif makro, globalisasi sepertinya sudah menjadi keharusan sejarah sebagai akibat kemajuan ilmu pengetahuan dan teknologi. Manusia adalah kreator dan sekaligus produk peradaban jaman, dan setiap jaman memiliki watak dan tantangannya sendiri. Bagi kebanyakan bangsa-bangsa Muslim, globalisasi pada umumnya dipersepsikan sebagai tantangan berat dan bahkan ancaman, termasuk ancaman di bidang pendidikannya. Sedang bagi negara-negara maju, globalisasi merupakan suatu peluang untuk melakukan ekspansi, termasuk ekspansi di bidang pendidikan mereka. Hal ini disebabkan karena globalisasi sepenuhnya dikendalikan oleh Negara-negara maju melalui regulasi yang dilakukan oleh tiga lembaga multilateral "gurita tritunggal" yaitu IMF, Bank Dunia dan WTO. 
Persoalan yang muncul adalah bagaimana pendidikan Islam mensikapi globalisasi?: Pertama, perlu mengambil sikap yang win-win solution (menang-menang), bukan lose-lose solution (kelompok Osama bin Laden), atau win-lose solution (menutup diri dari pengaruh globalisasi). Win-win solution, dilakukan dengan sikap hati-hati, kritis dan penuh rasa percaya diri, misalnya menerima untuk memasukkan "pengetahuan" sebagai salah satu kategori "komoditas" ke dalam General Agreement on Trade in Services (GATS) dengan persyaratanpersyaratan: (1) secara bertahab (progressive liberalization)- jangka pendek, menengah dan panjang; (2) dengan persyaratan-persyaratan tertentu seperti harus melindungi kepentingan nasional, dan tidak diboncengi oleh kepentingan-kepentingan ideologi dan budaya yang bertentangan dengan nilai dan ajaran Islam.

Kedua, mengembalikan watak pendidikan Islam yang sejati yai-tu internationalized (menginternasional/mendunia). Hal ini dilakukan dengan cara mengembangkan sikap terbuka dan positif terhadap pengaruh globalisasi yang positif seperti melimpahnya informasi yang dapat diakses dengan mudah dan cepat lewat internet, men-gembangkan pola kerjasama yang simetris dengan prinsip egalitaria-nism dan fairness. Kemajuan Islam di zaman klasik sangat didukung oleh semangat internasionalisasi, yaitu keterbukaan terhadap super power peradaban-peradaban pada waktu itu: Yunani, Romawi, Persia dan Cina yang kemudian diasimilasikan dan diakulturasikan dengan nilai dan semangat Islam. Dan dari sinilah akan melahirkan puncak peradaban Islam.

Semangat keterbukaan (inklusif) merupakan watak Islam, akan tetapi sekarang ini kebanyakan umat Islam bersifat tertutup (eksklusif). Tidak terlalu salah apabila dikatakan umat Islam sedang menghadapi masalah inferiority complex. Di satu sisi merasa paling benar, sebagai umat pilihan (khaira ummab), umat penengah (ummatan wasathan) yang bertugas menegakkan kebajikan dan mencegah kemungkaran (amar ma'ruf nabi munkar). Tetapi di sisi lain mengalami krisis kepercayaan diri dan ekskusif. Keadaan ini berdampak pada lembaga pendidikan yang diselenggarakanya. Pendidikan Islam yang watak dasarnya adalah menginternasional justru yang sering terlihat hanya sebagai sarana pewarisan ideologi politik kepartaian, paham 
keagamaan yang sempit dan untuk mempertahankan status quo fi rqah, mazhab dan golongan.

Ketiga, Membangkitkan kembali jiwa heroisme (semangat jihad) umat Islam di bidang pendidikan. Menurut data yang dirilis majalah Tempo, diantara komunitas penduduk dunia, umat Islam paling sedikit memiliki lembaga pendidikan dan paling sedikit memiliki ilmuwan, atau kalah dibanding dengan komunitas manapun di dunia. Fakta ini sungguh sangat memprihatinkan mengingat Islam adalah agama yang sangat menghargai ilmu pengetahuan, menjun-jung tinggi orang-orang yang menuntut ilmu dan dan para ulama serta mengecam orang yang bodoh karena tidak mau berfi kir dan tidak mau belajar. Membangkitkan kembali semangat jihad di bi-dang pendidikan pada dasarnya sama dengan kembali kepada Islam itu sendiri.

Fenomena kontemporer tentang gerakan-gerakan Islam memang sangat memprihatinkan dimana terdapat gerakan dakwah Islam yang berbasis di kampus-kampus, tetapi justru menghambat studi mahasiswa itu sendiri dan bahkan tidak sedikit yang akhirnya drop out. Ada juga gerakan Islam yang anti pemikiran. Padahal dengan melalui pemikiranlah ilmu pengetahuan dan teknologi dapat berkembang, kesejahteraan manusia meningkat, dan keimanan semakin mantap. Adalah sengat memilukan ketika Rasulullah diutus untuk melakukan pencerahan peradaban tetapi sebagian umatnya "memelintir" sedemikian rupa Islam sehingga menjadi anti peradaban.

Keempat, Pendidikan Islam harus melakukan penjaminan mutu sesuai dengan standar nasional dan internasional. Untuk dapat mencapai mutu, pendidikan Islam harus memperbaiki sistem manajerialnya, meningkatkan relevansi pendidikannya dengan kebutuhan dan perkembangan masyarakat, mengembangankan tata kelola yang baik (good governance) yang efektif produktif (effective productivity) dan senantiasa meningkatkan continuous quality improvement.

3. Globalisasi Pendidikan dan Misi Pendidikan Islam

Salah satu karakteristik globalisasi adalah integrasi, yaitu penggabungan menjadi satu kesatuan. Integrasi itu bukan hanya pada 
ekonomi, perdagangan dan pasar global, tetapi juga pada hukum, skill, pengetahuan, etos kerja, selera, harapan, pola hidup dan nilai. Fenomena McDonald, Coca-Cola, unilever, Sony, IBM dan lain sebagainya merupakan contoh nyata dari globalisasi. Melalui globalisasi pola hidup manusia dan kapital di seluruh dunia dapat dikendalikan oleh operator atau provider. Kuatnya pengaruh provider melewati kedaulatan Negara, pengaruh guru, ulama dan orangtua. Bahkan ada yang menganggap globalissi sebagai ideologi baru.

Ketika globalisasi pendidikan benar-benar telah berkembang, maka akan muncullah jenis dan model lembaga pendidikan global yang diekspor oleh Negara-negara maju ke Negara-negara berkembang tanpa bisa ditolak oleh pemerintah maupun masyarakat itu sendiri. Bagaikan McDonald yang mendesak warung/rumah makan ayam goreng lokal, lembaga-lembaga pendidikan global itu akan mendesak lembaga-lembaga pendidikan lokal semacam pesantren, madrasah, sekolah dan perguruan tinggi. Lembagalembaga pendidikan global itu dengan manajemen, proses pembelajaran dan mutu yang terstandarisasi internasional akan dengan mudah mendapatkan sambutan dari masyarakat, terutama kelas menengah ke atas.

\section{Sistem Pendidikan}

Era globalisasi dan faktor-faktor yang menyertainya mengharuskan adanya paradigma baru dalam pengelolaan pendidikan termasuk pendidikan Islam. Tanpa adanya perubahan paradigma dalam penyelenggaraan pendidikan, lembaga-lembaga pendidikan Islam (disadari atau tidak) akan mengalami krisis kepercayaan dan akan ditinggalkan oleh stake holder-nya. Yang menjadi persoalan adalah sistem pendidikan yang bagaimana yang dibutuhkan masyarakat pada era globalisasi seperti sekarang ini?

Berbicara tentang sistem pendidikan, biasanya tidak dapat dilepaskan dari komponen-komponen yang membentuk gugusan yang disebut lembaga dan organisasi pendidikan. Komponen-komponen itu biasanya berupa:

Komponen: Integritas (visi, misi, sasaran dan tujuan)

Komponen: Siswa (kriteria input, sistem penerimaan dan profil lulusan) 
Komponen: Guru dan tenaga pendukung (kriteria, sistem seleksi, profi 1 guru dan tenaga pendukung yang diharapkan, pola pengembangan staf)

Komponen: Kurikulum (substansi, relevansi, sekuensi) Komponen:

Penyelenggaraan (governance) yang meliputi: sistem nilai, sistem pengelolaan.

Komponen: Infrastuktur (physical infrastructure) yang meliputi prasarana dan sarana

Komponen: Finansial (financial) yang meliputi sumber dana, system alokasi dana, pengelolaan dan akuntabilitas.

Komponen: Sistem informasi yang meliputi: sistem dan kebijakan diseminasi informasi.

Yang menjadi persoalan adalah, bagaimana agar komponenkompenen tersebut dapat membentuk satu sistem pendidikan yang efektif. Sistem pendidikan yang efektif memiliki criteria yang disingkat RAISE, yang merupakan singkatan dari:

1. Relevance, yaitu keterkaitan tujuan maupun hasil/keluaran program pendidikan dengan kebutuhan masyarakat, pengguna lulusan dan misi Islam

2. Academic atmosphere, yaitu iklim pembelajaran yang mendukung interaksi edukatif yang kondusif guna mengoptimalkan proses pembelajaran

3. Institutional commitment, yaitu komitmen pemimpin dan staf untuk pengelolaan organisasi yang efektif dan produktif

4. Sustainability, yaitu keberlanjutan pennyelenggaraan pendidikan dan keberlanjutan peningkatan mutu pendidikan (continuous qual-ity improvement)

5. Efficiency, yaitu tingkat pemanfaatan segala sumber daya secara efi sien berdasarkan kelayakan (appropriateness) dan kecukupan (adequacy), serta tingkat ketercapaian tujuan yang telah ditetapkan.

Apabila suatu lembaga pendidikan dapat mencapai lima hal tersebut, maka sistem pendidikan itu disebut efektif. Pendidikan Islam terutama madrasah dan pesantren sudah seharusnya dapat membangun sistem pendidikannya secara efektif. Di sinilah pendidi- 
kan Islam menghadapi tantangan yang tidak ringan. Hampir semua komponen pendidikan menghadapi permasalahan yang serius, bahkan bisa dikatakan menghadapi siklus negatif atau menghadapi ling-karan setan tak terpecahkan (unsolved problems). Misalnya visi, misi, tujuan dan program kurang jelas dan kurang terfokus. Siswa sedikit dengan kualifi kasi di bawah stadar. Sumberdaya pendukung (guru, karyawan, pimpinan) terbatas kualitas, kuantitas dan kinerjanya. Kurikulum yang jarang ditinjau substansi, relevasi dan sequensinya; prasarana dan sarana yang terbatas baik kuantitas, kelayakan, pemeliharaan, pendayagunaan dan kelangsungannya. Finansial yang terbatas dalam sumber, jumlah, sistem pengelolaan, dan akuntabilitasnya. Sistem informasi, rancangan pengembangan sistem informasi yang terbatas dalam sarana pendukung (internet dan intranet) dan sistemnya yang kurang efisien dan efektif.

Persoalan-persoalan pada masing-masing komponen pendidikan tersebut saling berkaitan satu dengan lainnya, yang menjadi persoalan adalah bagaimana merubah siklus negatif menjadi siklus positif, atau bagaimana merubah dari lingkaran setan menjadi lingkaran malaikat?

Berbagai penelitian menunjukkan bahwa untuk merubah dari siklus negatif menjadi siklus positif atau untuk merubah dari sekolah yang tidak berkualitas (bad school) menjadi berkualitas (good school), faktor kepemimpinan memegang peran sangat menentukan. Lembaga pendidikan yang baik dipimpin oleh pemimpin yang baik, walaupun tidak semua pemimpin yang baik mampu menjadikan lembaga pendidikan menjadi baik. Bagi lembaga pendidikan Islam yang menghadapi persoalan berat dan misi yang sangat mulia (pendidikan dan dakwah), perlu dipimpin oleh pemimpin yang memiliki kekua-tan luar biasa. Model kepemimpinan konvensional seperti kepemimpinan situasional, transaksional dan transformasional, perlu disempurnakan dengan model kepemimpinan spiritual. Kepemimpinan spiritual adalah kepemimpinan yang mendasarkan visi, misi dan perilaku kepemimpinannya pada nilai-nilai ketuhanan.

\section{E. Potret Pendidikan Islam}

Panggilan Islam kepada umatnya untuk berhidmat di bidang 
pendidikan, ilmu pengetahuan dan dakwah sangat kuat. Hal ini dapat dilihat dari nash-nash al-Qur'an, Hadis, maupun tindakan Rasulullah dan generasi sesudahnya sampai abad ke-13 Masehi. Kepedulian umat Islam terhadap pendidikan, ilmu pengetahuan dan dakwah seiring sejalan dengan kemajuan peradaban umat dan pesatnya perkembangan Islam di berbagai penjuru dunia. Pendidikan adalah media yang paling strategis bagi umat Islam untuk mengaktualisasikan fungsi dan perannya sebagai pemeran utama pengembangan peradaban dunia yang didasari oleh nilai-nilai akhlakul karimah. Pasca abad ke-13 Masehi sampai pertengahan abad ke-20 kepedulian umat Islam di bidang pendidikan terus merosot.

Pasca penjajahan bangsa-bangsa Barat, semangat umat mendirikan lembaga pendidikan Islam dalam berbagai jenis dan jenjangnya secara kuantitas mulai bangkit. Akan tetapi semangat itu pada umumnya tidak disertai dengan kapasitas (kekuatan) dan kapabilitas (kecakapan) yang memadai baik wawasan, pendanaan maupun manajemennya. Akibatnya sebagian besar lembaga pendidikan Islam itu menghadapi berbagai persoalan (kualitas, relevansi) dan siklus negatif (vicious circle). Pendidikan Islam yang diibaratkan baru tumbuh (masa infatil) itu sekarang menghadapi ujian berat yaitu globalisasi, dengan segala kekuatan, kecanggihan, karakusan dan ket-amaannya siap menggilas pendidikan negaranegara sedang berkembang termasuk pendidikan Islam.

Dalam konteks internal masing-masing negara, pendidikan Islam juga menghadapi masalah:

1. Ketidakjelasan konsep pendidikan Islam itu sendiri sehingga menimbulkan dualisme pendidikan, yaitu pendidikan umum (sekolah) dan pendidikan Islam (madrasah dan pesantren)

2. Tradisi oposisi umat terhadap pemerintah masing-masing. Hal ini berdampak pada kurangnya perhatian pemerintah terhadap pendidikan Islam. Pendidikan Islam seringkali dijadikan basis gerakan dan memproduksi paham oposisi terhadap pemerintah sehingga pemerintah merasa kurang berkepentingan untuk mengebangkannya dan bahkan kalau perlu dikooptasi atau dimatikan. Di Indonesia misalnya, madrasah dan pesantren selama pemerintahan Orde Baru dapat dikatakan sebagai sebagai 
forgotten community (komunitas terlupakan) dan peripheral community (komunitas pinggiran).

3. Pendidikan Islam lebih banyak berfugsi sebagai cagar budaya dan bahkan polarisasi budaya dan sosial dari friksi-friksi pemahaman dan faksi-faksi gerakan Islam yang ada.

4. Dalam tradisi pembelajaran, masih kuatnya sistem pembelajaran yang konvensional dan tidak berorientasi pada bidang keahlian yang spesifik, dualisme ilmu umum-ilmu agama, masih adanya paham yang tidak diperbolehkannya atau malu-malu untuk me-mungut bayaran untuk kegiatan pembelajaran (tidak menghar-gai profesi guru) dan masih adanya anggapan bahwa menuntut ilmu agama hukumnya fardlu a'in dan fardlu kifayah untuk ilmu umum

5. kondisi fisik dan fasilitas pada umumnya sangat terbatas sehingga tidak melahirkan kenyamanan dan tidak menarik, tidak didukug oleh SDM yang memadai.

Di bidang manajemen kelembagaan, problem yang dihadapi pendidikan Islam antara lain:

1. Visi dan misi biasanya belum terumuskan dengan jelas, belum tersosialisasikan dan belum menjadi acuan kerja

2. Sebagian besar pendidikan Islam terutama pesantren dan madrasah adalah milik perorangan sehingga menghambat partsisipasi publik untuk memajukannya

3. Sebagian besar belum memiliki badan hukum, sehingga rawan konfl ik dan perpecahan

4. Komponen-komponen dalam sistem pendidikannya kurang memiliki kelayakan (appropriateness) dan kecukupan (adequacy).

5. Kepemimpinan pada umumnya bersifat tradisional dan sangat tergantung pada person (central figure).

6. Sistem administrasi pada umumnya sangat lemah.

7. Budaya mutu pada umumnya masih sangat rendah.

Akibat keadaan di atas, lembaga pendidikan Islam menghadapi permasalahan sebagai berikut:

1. Relevansi penyelenggaraan pendidikan Islam dengan kebutu- 
han masyarakat dan pengguna lulusan rendah

2. Academic atmosphere, yaitu iklim dan suasana pada umumnya belum mendukung prestasi

3. Institutional commitment mulai pimpinan, guru, dan karyawan terhadap pengelolaan organisasi yang efektif dan produktif tidak bisa berjalan secara maksimal.

4. Sustainability (keberlanjutan) belum terjamin

5. Efficiency and productivity rendah.

\section{F. Model Manajemen dan Kepemimpinan yang Tepat untuk}

\section{Mengembangkan Pendidikan Islam}

Dari perspektif sejarah, lembaga-lembaga pendidikan Islam khususnya madrasah dan pesantren itu tumbuh dari bawah, dari gagasan tokoh-tokoh agama setempat. Diawali dari pengajian yang lantas mendirikan mushalla/masjid, madrasah diniyah, dan kemudian mendirikan pesantren atau madrasah. Sebagian besar tumbuh dan berkembang dari kecil dan kondisinya serba terbatas. Selanjutnya ada yang tubuh dan berkembang dengan pesat atau mengalami continuous quality improvement, ada juga yang stagnant (jalan di tempat) dan ada pula yang mati. Bagi yang terus berkembang hingga mampu mendirikan lembaga-lembaga pendidikan umum dan perguruan tinggi, didukung oleh usaha-usaha lain yang bersifat profi t seperti pertanian, perdagangan, percetakan, industri jasa dan lain sebagainya.

Sejak dekade 90 -an, kesadaran umat untuk meningkatkan mutu lembaga pendidikan Islam mulai bangkit dimana-mana dan beber-apa di antaranya telah mampu menjadi sekolah unggul atau sekolah yang efektif (effective schoo). ${ }^{6}$ Yang menjadi persoalan dalam model manajemen yang bagaimana yang tepat bagi pendidikan Islam yang memiliki karakteristik tersebut?

1. Manajemen yang Bernuansa Entrepreneurship

Sebagaimana dikemukakan di muka bahwa sebagian besar

6 Azyumardi Azra, Pendidikan Islam Tradisi dan Modernisasi Menuju Milin-ium Baru. (Jakarta: 2000) hlm. 31. 
pendidikan Islam tumbuh dan berkembang dari bawah dan dari kecil. Manajemen yang tepat adalah manajemen yang dapat memberikan nilai tambah. Manajemen yang dapat memberi nilai tambah adalah manajemen yang bernuansa entrepreneurship. Rhenald Kasali dalam Paulus Winarto ${ }^{7}$ menegaskan bahwa seorang entrepreneur adalah seorang yang menyukai perubahan, melakukan berbagai temuan yang membedakan dirinya dengan orang lain, menciptakan nilai tambah, memberikan manfaat bagi dirinya dan orang lain, karyanya dibangun berkelanjutan (bukan ledakan sesaat) dan dilembagakan agar kelak dapat bekerja dengan efektif di tangan orang lain. Seorang manajer yang sekaligus sebagai seorang entrepreneur memiliki karakter sebagai berikut: memiliki keberanian mengambil resiko, menyukai tantangan, punya daya tahan yang tinggi punya visi jauh ke depan dan selalu berusaha memberikan yang terbaik.

Menjadi seorang entrepreneur diperlukan integritas yang kokoh, memiliki etos kerja yang tinggi dan kesanggupan untuk menghadapi tantangan, hambatan dan bahkan ancaman. Seorang entrepreneur adalah orang yang berani mengambil keputusan "keluar dari zona nyaman dan masuk ke dalam zona ketidakpastian (penuh resiko)". Manajer yang biasa (konvensional) sebenarnya adalah orang yang paling membutuhkan keamanan dan status quo, dan sebaliknya takut pada perubahan. Hal ini wajar karena ia sedang berada di puncak piramida dalam struktur organisasi dengan segala fasilitas, kedudukan dan kehormatan yang melekat padanya.

Seorang entrepreneur pada dasarnya adalah seorang pembaharu (innovator) karena melakukan sesuatu yang baru, dianggap baru atau berbeda dari kondisi sebelumnya. Apa yang dilakukan itu membawa perubahan ke arah yang lebih baik dan memberi nilai tambah bagi diri maupun orang lain. Dalam upaya untuk menciptakan nilai tam-bah seorang entrepreneur sangat mengutamakan kekuatan brand, yaitu citra atau merek yang kuat atas apa yang dilakukannya. Dengan brand yang baik jelas akan memberikan value yang tinggi. Brand image bagi sebuah lembaga pendidikan merupakan aset yang paling berharga

${ }^{7}$ Paulus Winarto, First Step to be an Entrepreneur. (Jakarta: Elex Media Komputindo. 2003) hlm. 3. 
yang mampu menciptakan value bagi stakeholder dengan meningkat-kan kepuasan dan menghargai kualitas dan akhirnya melahirkan kepercayaan. Seorang manajer yang sekaligusentrepreneur bukan sekedar bisa membangun brand belaka, namun juga memanfaatkan kekuatan brand untuk melipatgandakan akselerasi sebuah perubahan.

Pesan Kyai Dahlan (KH. Ahmad Dahlan) agar meng"hiduphidupi Muhammadiyah dan jangan mencari hidup di Muhammadiyah" dapat ditafsirkan dalam konteks semangat entrepreneurship. Artinya setiap orang yang bekerja di lembaga amal usaha Muhammadiyah harus mampu memberikan nilai tambah bagi perkembangan lembaganya. Dengan cara inilah akan terjadi penumpukan capi-tal (capital development) sehingga amal usaha Muhammadiyah dapat terus tumbuh dan berkembang.

2. Management based society, yaitu manajemen yang dapat menjaga hubungan baik dengan masyarakat sekitar.

Data EMIS Departemen agama menunjukkan 90\% madrasah berstatus swasta dan $100 \%$ pesantren adalah swasta. ${ }^{8}$ Ini berarti bahwa lembaga pendidikan Islam adalah lembaga milik masyarakat, atau bisa dikatakan "dari, oleh dan untuk masyarakat". Manajemen pendidikan Islam yang tepat adalah manajemen yang dapat mendekatkan pendidikan Islam dengan masyarakat, diterima, dimiliki dan dibanggakan oleh masyarakat dan dapat mendayagunakan potensi-potensi yang dimiliki masyarakatnya. Konsep Manajemen berbasis sekolah (Management Based School) dan pendidikan berbasis masyarakat (Society Based Education) dalam konteks otonomi daerah, lahir karena dilandasi oleh kesadaran bahwa masyarakat punya peran dan tanggung jawab terhadap lembaga pendidikan di daerahya di samping sekolah dan pemerintah.

Bagi lembaga pendidikan Islam yang memang "dari, oleh dan untuk masyarakat", maka mengembalikan pendidikan Islam kepada masyarakat merupakan sebuah keniscayaan apabila pendidikan Islam ingin mengambil dan mendayagunakan kekuatannya. Dengan kata lain, masyarakat adalah kekuatan utama pendidikan Islam.

${ }^{8}$ www.bagais.go.id. 
Mencabut pendidikan Islam dari grass root nya (masyarakat) justru akan memperlemah pendidikan Islam itu sendiri. Pondok pesantren yang mampu menjaga hubungan baiknya dengan basis sosialnya terbukti dapat terus berkembang, dan sebaliknya akan mengalami surut ke-tika ditinggalkan oleh masyarakatnya.

Lembaga-lembaga pendidikan di Negara-negara maju terutama yang berstatus privat pada umumnya terdapat lembaga semacam Dewan Sekolah, Majlis Madrasah, Dewan Penyantun, Majlis Wali Ama-nah dan lain sebagainya yang antara lain bertugas memperhatikan hubungan, kedekatan dan aspirasi masyarakat serta siap mendayagunakan potensi masyarakat dan memberikan layanan pengabdian (langsung maupun tidak langsung) kepada masyarakat. Di Stanford University misalnya ada The Board of Trustees yang berwenang mengelola dana hibah dan hadiah (grand), sumbangan (endowment) dan lain sebagainya yang dihimpun dari dana masyarakat untuk pengembangan Stanford University.

Di Negara-negara persemakmuran seperti di University of London United Kingdom dan McGill University Canada misalnya terdapat lembaga yang namanya Board of Governor. Anggota lembaga ini sebagian besar dari luar universitas yang pada umumnya memiliki tugas dan peran sebagaimana The Board of Trustees pada Stanford University. McGill University misalnya, lembaga ini dapat berkembang karena semangat amal dari masyarakatnya. Diawali dari hibah James McGill yang menghibahkan sebagian kekayaannya berupa uang 10.000 pound sterling dan tanah 40 hektar beserta real estat yang ada di dalamnya, lembaga ini didirikan dan berkembang dengan terus menggali dana dari masyarakat sampai sekarang. Di McGill, semangat beramal itu tidak hanya dalam pengertian materi terutama dari para dermawan dan hartawan, tetapi juga perbuatan. Dosen, karyawan dan pimpinan McGill rela bekerja keras karena dilandasi oleh semangat amal, semangat beribadah.

Semangat beramal untuk membangun lembaga pendidikan dalam tradisi iman umat Islam sebenarnya bukan sesuatu yang baru, bahkan umat Islam pernah menjadi pelopor (avant-garde) dalam komitmennya mengembangkan lembaga pendidikan melalui semangat amal. Yang menjadi persoalan sekarang adalah, bagaimana mem- 
bangkitkan kembali semangat beramal ini dalam mengembangkan pendidikan Islam? Pertama, adanya lembaga semacam Board of Trustees atau semacam Majlis Wali Amanah yang anggotanya dari wakil masyarakat yang memiliki integritas dan komitmen yang tinggi terhadap pendidikan Islam. Kedua, perlu dibangkitkan kembali semangat juang (jihad), etos kerja semua komponen stake holder internal sebagai wujud amal (perbuatan) nyata. Ketiga, perlu diterapkan manajemen mutu terpadu (total quality management) dalam penyelenggaraan pendidikan Islam.

3. Management Based Mosque atau Manajemen Berbasis Masjid.

Sebagaimana dikemukakan di muka, embrio pendidikan Islam adalah Masjid. Manajemen pendidikan Islam yang berbasis masjid adalah manajemen yang dijiwai oleh nilai dan semangat spiritual, semangat berjamaah, semangat ikhlas lillabi ta'ala (ikhlas karena Allah) dan semangat memberi yang hanya berharap pada ridlo Allah. Proses pembelajaran yang integratif dengan masjid memberikan nuansa religius yang kental dalam penanaman nilainilai religius maupun praktek langsung pengalaman beragama. Dimulai dari pembiasaan shalat dluha, shalat dluhur berjamaah dan shalat Ashar berjamaah bagi yang full day school.

Akhir-akhir ini banyak lembaga pendidikan Islam yang berkualitas yang berbasis masjid seperti SD Islam al-Falah Surabaya, SD-SMP Islam al-Hikmah Surabaya, dan SD Islam Sabilillah Malang. Management Based Mosque bukan hanya berarti lokasi sekolah itu di dekat masjid, melainkan sifat-sifat keutamaan dalam masjid dapat ditransfer dalam mengelola lembaga pendidikan Islam. Di samping itu, perlu dikembangkan hubungan sinergis antara masjid, lembaga pendidikan dan jamaah.

\section{G. Model Kepemimpinan yang Tepat}

Beberapa hasil penelitian menunjukkan hubungan yang signifikan antara kepemimpinan pendidikan yang efektif dengan sekolah yang efektif. Penelitian Edmonds ${ }^{9}$ mengemukakan, sekolah-sekolah

${ }^{9}$ Edmonds, R. Some Schools Work and More Can, Social Policy, Vol. 9, No. 2, 1979, hlm. 28-32. 
yang dinamis yang senantiasa berupaya meningkatkan prestasi kerjanya dipimpin oleh kepala sekolah yang baik. Penelitian Hallinger dan Lithwood menyimpulkan bahwa sekolah yang efektif senantiasa dipimpin oleh kepala sekolah yang efektif pula. Kedua penelitian tersebut didasarkan pada asumsi bahwa kepala sekolah merupakan pemimpin dan salah satu agen perubahan sekolah yang terpenting. Kepala sekolah yang memiliki kepemimpinan yang kuat menurut Blumberg dan Greenfi eld mampu memerankan diri dalam delapan peran: organisator (the organizer), pengakrobat berdasarkan nilai (the value-based juggler), penolong sejati (the authentic belper), perantara (the broker), humanis (the bumanist), katalis (the catalyst), rasionalis (the ratio-nalist), dan politikus (the politician).

Indonesia sebagai negeri muslim terbesar di dunia memiliki jumlah lembaga pendidikan yang paling besar pula. Dua organisasi sosial keagamaan terbesar yaitu NU dan Muhammadiyah sangat peduli dengan persoalan pendidikan sehingga memiliki lembaga pendidikan dari TK sampai perguruan tinggi yang berjumlah ribuan. Di samping itu terdapat gerakan Islam yang tergolong berusia muda dan memiliki kepedulian yang tinggi terhadap pendidikan yaitu Tarbiyah juga memiliki banyak lembaga pendidikan Islam.

Namun demikian, kuantitas lembaga pendidikan Islam belum sebanding dengan kualitasnya. Hal ini antara lain disebabkan oleh sedikitnya pemimpin atau tokoh pendidikan yang dapat diandalkan. Persoalannya adalah model kepemimpinan yang bagaimana yang cocok dan mampu merubah pendidikan Islam dari kecil menjadi besar, dari tidak diminati menjadi berprestasi? Model kepemimpinan yang dimaksud tentu bukan model kepemimpinan yang biasa, melainkan kepemimpinan yang luar biasa. Model kepemimpinan apakah itu ?

Sebenarnya tidak ada model kepemimpinan yang secara umum paling baik, atau sebaliknya model kepemimpinan yang jelek. Semua model kepemimpinan pada dasarnya adalah baik. Pertama, sebuah model kepemimpinan menjadi baik atau tidak, bukan ditentukan oleh standar normatif (benchmark) dari model kepemimpinan itu sendiri melainkan seberapa jauh relevan dengan konteks persoa-lan dan tujuannya serta personality dan style of leadership seorang pemimpin. 
Kedua, apapun model kepemimpinannya, harus disertai dengan kesungguhan, ketulusan, komitmen dan dedikasi. Ketiga, yang menyebabkan seorang pemimpin pendidikan mengalami kega-galan seringkali bukan karena menerapkan model kepemimpinan tertetu atau mengkombinasikan beberapa model kepemimpinan. Sebaliknya justru kepemimpinannya tidak memiliki model dan style, sehingga nyaris tidak ada kelebihannya, tidak bisa dipegangi dan ti-dak menghasilkan apa-apa. Dengan kata lain, yang menyebabkan sebuah lembaga pendidikan mengalami kegagalan adalah karena ti-dak adanya kepemimpinan meskipun kepala sekolahnya selalu ada.

Meskipun demikian, berikut ini dikemukakan beberapa model kepemimpinan yang paling relevan dengan persoalan pendidikan berdasarkan hasil penelitian yang penulis lakukan maupun berdasar-kan ijtihad semata:

\section{Model Kepemimpinan Situasional}

Kepemimpinan situasional adalah perilaku seorang pemimpin berasarkan pada tiga hal: kekuatan dalam diri pemimpin, kekuatan dalam diri orang-orang yang dipimpin, dan kekuatan dalam situasi. Perilaku pemimpin sangat tergantung pada situasi, yaitu tingkat hubugan kerja dan tingkat kematangan staf dalam melaksanakan tugas. Pertama, ketika tingkat hubungan kerja dan tingkat kemata-gan staf dalam melaksanakan tugas tinggi, maka perilaku pemimpin bersifat partisipatif. Dia menjadi seorang pemimpin yang demokratis. Kedua, ketika hubungan kerja rendah tetapi tingkat kematangan staf dalam melaksanakan tugas tinggi, maka perilaku pemimpin akan bersifat delegatif. Dia berperilaku layaknya pemimpin transformatif, yaitu mentransformasikan nilai, tugas dan wewenang yang dia miliki kepada yang dipimpin setelah sebelumnya membangun trust dan rasa saling percaya. Namun ketika rasa saling percaya itu rendah, seorang peimpin harus banyak melakukan pengecekan, kontrol, dan pengawasan. Ketiga, ketika hubungan kerja tinggi tetapi tingkat kematangan staf dalam melaksanakan tugas rendah, maka perilaku pemimpin akan bersifat konsultatif, berada di depan dan banyak memberikan contoh dan bisa juga berperan sebagai seorang konsultan. Dia mungkin akan menjadi pemimpin kharismatik. Keempat, ketika tingkat hubungan kerja rendah dan tingkat kematangan staf 
dalam melaksanakan tugas juga rendah, maka perilaku pemimpin bersifat instruktif. Kecenderungannya akan menerapkan model kepemimpinan otoriter.

\section{Model Kepemimpinan Spiritual}

Istilah kepemimpinan spiritual (spiritual leadership) merupakan konsep yang penulis temukan berdasarkan hasil penelitian tentang model kepemimpinan yang tepat untuk pembaharuan pendidikan Islam. ${ }^{10}$ Kepemimpinan spiritual adalah model kepemimpinan yang lebih mengedepankan nilai-nilai ruhani atau spiritualitas untuk mempengaruhi, mengilhami, mencerahkan dan memberdayakan orang-orang yang dipimpin. Kata spirit dalam istilah kepemimpinan spiritual berarti yang ruhani (yang abadi). Dalam kehidupan ini yang abadi hanyalah Allah. Karena itu kepemimpinan spiritual adalah model kepemimpinan yang meniru atau mencontoh kepemimpinan Tuhan, terutama lewat sifat-sifat robbaninya. Dalam perspektif Islam, dimensi spiritualitas senantiasa berkaitan secara langsung dengan realitas Ilahi, Tuhan Yang Maha Esa (taubid). Spiritualitas bukan sesuatu yang asing bagi manusia, karena merupakan inti (core) kemanusiaan itu sendiri.

Kalau model kepemimpinan lain perilakunya berdasarkan hal ihwal yang kasat mata (sin) seperti reward dan punishman, maka kepemimpinan spiritual lebih mendasarkan pada fenomena yang tidak kasat mata (unseen), yaitu keimanan dan hati nurani. Perilaku manusia yang kasat mata ini sesungguhnya cerminan dari hati nuraninya. Dalam sebuah hadis dikatakan bahwa kualitas manusia itu tergantung pada kualitas hatinya, dan pepatah arab mengatakan bahwa yang lahir (seen) itu merupakan cermin dari yang batin (unseen).

Beberapa istilah model kepemimpinan yang mendekati konsep kepemimpinan spiritual adalah kepemimpinan atas nama Tuhan, ${ }^{11}$ the corporate mystic menurut Hendricks dan Ludeman ${ }^{12}$,kepemimpi-

${ }^{10}$ Tobroni. The Spiritual Leadership. Malang: UMM Press. 2005.

${ }^{11}$ Percy, lan. 2003. Going Deep. Exploring Spirituality in Life and Leadership. Arizona: Inspired Production Press.

${ }^{12}$ Hendricks Gay dan Kate Ludeman. 2002. The Corporate Mystic (terj. Fahmy Yamani). Bandung: Kaifa 
nan dimensi keempat, kepemimpinan yang mengembangkan kecerdasan emosi menurut Goleman ${ }^{13}$, executive EQ menurut Cooper dan Sawaf, dan powerful leaders menurut Ary Ginanjar Agustian.

Kepemimpinan spiritual adalah kepemimpinan yang membawa dimensi keduniawian kepada dimensi spiritual (kellahian). Tuhan adalah pemimpin sejati yang mengilhami, mencerahkan, membersihkan hati nurani dan memenangkan jiwa hamba-Nya dengan cara yang sangat bijaksana melalui pendekatan etis dan keteladanan.

Dalam perspektif sejarah Islam, kepemimpinan spiritual barangkali dapat merujuk kepada pola kepemimpinan yang diterapkan oleh Muhammad SAW. Dengan integritasnya yang luar biasa dan mendapatkan gelar sebagai al-amîn (terpercaya), Muhammad SAW mampu mengembangkan kepemimpinan yang paling ideal dan paling sukses dalam sejarah peradaban umat manusia. Sifat-sifatnya yang utama yaitu siddîq (integrity), amanah (trust), fathanah (working smart) dantabligh (openly, buman relation) mampu mempengaruhi orang lain dengan cara mengilhami tanpa mengindoktrinasi, menyadarkan tanpa menyakiti, membangkitkan tanpa memaksa dan mengajak tanpa memerintah.

Secara kuantitas jumlah Pendidikan Islam di Indonesia sangat besar (banyak), secara kualitas kecil (rendah), namun demikian menghadapi permasalahan yang besar (banyak dan berat). Untuk itu diperlukan seorang pemimpin yang berjiwa dan berpikiran besar: inilah pemimpin yang meniru kepemimpinan Tuhan, menjadi "pipa” penyalur rahmat Tuhan.

\footnotetext{
${ }^{13}$ Goleman, Daniel. 1999. Working With Emotional Intelligence, New York: Bantam Books
} 


\section{DAFTAR PUSTAKA}

Azyumardi Azra, 2000, Pendidikan Islam Tradisi dan Modernisasi Menuju Milinium Baru, Jakarta.

Badan Akreditasi Nasional Perguruan Tinggi, 2005, Depdiknas.

Edmonds, R, 1979, Some Schools Work and More Can, Social Policy, Vol. 9, No. 2.

Effendi, Sofian, 2007, Menghadapi Liberalisasi Pendidikan Tinggi, http//www.google.com

Gay, Hendricks dan Kate Ludeman, 2002, The Corporate Mystic (terj. Fahmy Yamani), Bandung: Kaifa.

Goleman, Daniel, 1999, Working With Emotional Intelligence, New York: Bantam Books.

Paulus Winarto, 2003, First Step to be an Entrepreneur. Jakarta: Elex Media Komputindo.

Percy, Ian, 2003, Going Deep. Exploring Spirituality in Life and Leader Ship, Arizona: Inspired Production Press.

Tobroni, 2005, The Spiritual Leadership. Malang: UMM Press. www.bagais.go.id. 
